\title{
THE CONTINGENT FEE IN CANADA
}

\author{
WALTER B. WILLISTON, Q.C.*
}

\begin{abstract}
Mr. Williston feels that the historical abhorence of contingent fees is obsolete in the face of modern social conditions. He discusses the approach to contingent fees in various jurisdictions and the benefits and drawbacks of the different systems. Mr. Williston concludes that a controlled system of contingent fees would be a valuable contribution to the Canadian legal system.
\end{abstract}

Nowhere in the philosophy of law can there be found a greater divergence of opinion than on the question of the propriety of a solicitor accepting compensation on the basis of a "contingent fee." In Great Britain and in the majority of the Provinces of Canada the contingent fee is regarded as unprofessional and attached thereto is a stigma approaching legal leprosy. In the United States of America, the contingent fee is considered to be the normal and usual method of compensation, especially in personal injury actions. Without completely accepting the contingent fee as an untarnished mode of obtaining remuneration, certain of the Provinces of Canada have, either by judicial pronouncement or by express enactment, permitted it to exist. The purpose of this article is to examine historically the reasons for the abhorence of the contingent fee and to consider whether these reasons are now valid.

The aversion to the contingent fee was engendered at a time when jurists regarded any interference in the litigation of others as vexatious and the undue promotion of strife, and denounced it on the ground of maintenance. The question today may be: is this position valid when Unions constantly pay the legal costs of their members, when most of the expenses of accident litigation are borne by insurance companies and governments themselves subsidize litigation for indigent parties? A free legal aid plan, although admirable and a move in the direction of social justice, is undisguised maintenance by the State. Furthermore, is the situation affected by the fact that Parliament has now abolished the crime of maintenance?

The position is perhaps best summarized in the rhetorical question asked by Danckwerts, J., in Martel v. Consett Iron Co., Ltd. ${ }^{1}$

How can such a doctrine founded on considerations of public policy become at some point frozen into immutable respectability, so as to be no longer capable of alteration?

In Weld-Blundell v. Stephens, ${ }^{2}$ Lord Dunedin described the action of maintenance as "a cumbersome curiosity of English law". But perhaps the most illuminating case in English jurisprudence dealing with the history and the rationale of the law of maintenance is Neville v. London "Express" Newspaper, Limited, ${ }^{3}$ in which a full discussion of the earlier authorities is made by Lord Finlay:

Maintenance in a court of justice is defined in Hawkins' Pleas of the Crown (8th ed., published in 1824, vol. 1, c. $27(6)$, s. 3, at p. 454) as being 'where one

- Of the Toronto firm of Fasken, Clavin, MacKenzie, Williston \& Swackhamer. The writer is indebted to Brian Finlay, B.A., LL.B. (Tor.) for the research which formed the basis of this article.

1 1954] 3 All E.R. 339, 347 (Ch. Div.); aff. [1955] 1 All E.R. 481 (C.A.).

2 [1920] A.C. $957,977$. 
officiously intermeddles in a suit depending in any such court which no way belongs to him, by assisting either party with money, or otherwise, in the prosecution or defence of any such suit.' He goes on to point out, however, that acts of this kind may be justified in various cases-e.g., if there is an interest in the thing at variance, in respect of kindred or affinity, in respect of other relations as lord and tenant or master and servant, or in respect of charity. In s. 26, p. 460 , the learned author says: 'It seems to be agreed, that anyone may lawfully give money to a poor man to enable him to carry on his suit.' In s. 38, p. 462, he says: 'It seemeth that all maintenance is strictly prohibited by the common law, as having a manifest tendency to oppression, by encouraging and assisting persons to persist in suits, which perhaps they would not venture to go on in upon their own bottoms; and therefore it is said, that all offenders of this kind are not only liable to an action of maintenance at the suit of the party grieved, wherein they shall render such damages as shall be answerable to the injury done to the plaintiff, but also that they may be indicted as offenders against public justice, and adjudged thereupon to such fine and imprisonment as shall be agreeable to the circumstances of the offence. Also it seemeth, that a court of record may commit a man for an act of maintenance done in the face of the Court.'

The essence of the offence is intermeddling with litigation in which the intermeddler has no concern, unless the case falls under some of the heads of exception to which I have above adverted. It was considered that it is against public policy that litigation should be promoted and supported by those who had no concern in it. Blackstone in his Commentaries (Book IV., c. 10, s. 12) after reproducing in substance Hawkins' definition of maintenance says: 'This is an offence against public justice, as it keeps alive strife and contention, and perverts the remedial process of the law into an engine of oppression.' Lord Coke in the Second Institute (p. 212) defines maintenance thus: 'Maintenance is an unlawful upholding of the demandant or plaintiff, tenant or defendant in a cause depending in suit, by word, writing, countenance, or deed. This maintenance (as hath been said) is malum in se, and against the common law, and that is notably proved by this Act'. (Westminster 1st c. 28), 'for hereby maintenance is branded with this quality and that thereby common right is delaied, or disturbed, and consequently against the common law.'4

\section{Lord Phillimore in the same case stated:}

The law of maintenance is stated in the textbooks to be in itself part of the common law though affirmed or declared and supported by various ancient statutes. These, as I gather, at any rate those which were brought to your Lordships' notice, are the following:-

3 Edw. I. cc. $25,28$.

$20 \mathrm{Edw}$. I. Ordinance concerning conspirators.

$28 \mathrm{Edw}$. I. c. 11.

1 Edw. III. st. 2, c. 14.

4 Edw. III. c. 11 .

1 Rich. II. c. 4.

7 Rich. II. c. 15.

32 Hen. VIII. c. 9,

which have been analyzed by my noble and learned friend, Lord Shaw, and to which I would add 3 Hen. VII. c. 1 .

A perusal of these statutes shows that in the days when they were enacted the ordinary subject of the King found great difficulty in procuring a fair trial when his adversary was in some privileged position. Sometimes the King's officers were induced by a bribe or by the offer of a share of the spoil to favour his adversary. Sometimes great men gave countenance to his adversary, sometimes confederacies were formed to support unjust claims or defences. And the statutes are directed against maintenance, champerty and confederacy or conspiracy, while embracery or subornation of perjury were some of the means used to secure these unlawful ends. ${ }^{5}$

There remain the institutional writers of the eighteenth century, Hawkins and Blackstone, whose language has been quoted by Lord Shaw.

In their view the evil of maintenance lay in the stirring up of strife. My Lords, I think this was bad archaeology. Maintenance is on a par with champerty, conspiracy and embracery. The doctrine was established to prevent injustice. ${ }^{6}$

4 Id., at 378, 382.

5 Id., at 426 .

o Id., at 433 . 


\section{Lord Esher in Alabaster v. Harness ${ }^{7}$ stated:}

The doctrine of maintenance ... does not appear to me to be founded so much on general principles of right and wrong or of natural justice as on considerations of public policy. I do not know that, apart from any specific law on the subject, there would necessarily be anything wrong in assisting another man in his litigation. But it seems to have been thought that litigation might be increased in a way that would be mischievous to the public interest if it could be encouraged and assisted by persons who would not be responsible for the consequences of it, when unsuccessful.

Whatever was the exact reason which gave rise to the principle of maintenance and champerty, the early common law was ready and anxious to extend its ambit. Courts would not enforce any agreement or other instrument which "so savour of" such offences as to be "mischievous", "against good policy and justice" and "tending to promote unnecessary litigation." In 1852, Knight Bruce, L. J., in the case of Reynell v. $S p r y e^{8}$ propounded the following principle:

Such an understanding, such an agreement ... may or may not have amounted strictly in point of law to champerty or maintenance so as to constitute a punishable offense, but must ... be considered clearly against the policy of the law, clearly mischievous, clearly such as a Court of Equity ought to discourage and relieve against.

While there has been some relaxation in the rigidity of the law relating to maintenance in recent times, a person is still guilty of maintenance if he supports litigation in which he has "no legitimate concern" or does so without "just cause or excuse." However, the bounds of "legitimate concern" have widened and "just cause or excuse" is more readily found. As stated by Lord Denning in Hill v. Archbold: ${ }^{\circ}$

This new approach means that we must look afresh at the previous cases. In particular at two cases on which Mr. Hill relies. The first is Oram v. Hutt. In that case a man had slandered the general secretary of a trade union, accusing him of misconduct in the affairs of the union. The executive committee of the trade union authorized the general secretary to sue for slander and agreed to indemnify him against the costs. The general secretary won. He got judgments for $£ 1,000$ and costs; but the defendant could not pay anything. So the trade union paid the costs incurred by the general secretary. One of the members of the union then sued the trustees of the union claiming that the payments were illegal. It was held by this court, consisting of Lord Parker of Waddington, Lord Sumner and Warrington, J., that the payment was obnoxious to the law of maintenance. They ordered the general secretary to repay the money. ...

It is now over fifty years since Oram v. Hutt was decided. I prefer to say plainly that Oram v. Hutt is no longer good law. Much maintenance is considered justifiable today which would in 1914 have been considered obnoxious. Most of the actions in our courts are supported by some association or other, or by the State itself. Very few litigants bring suits, or defend them, at their own expense. Most claims by workmen against their employers are paid for by a trade union. Most defences of motorists are paid for by insurance companies. This is perfectly justifiable and is accepted by everyone as lawful, provided always that the one who supports the litigation, if it fails, pays the costs of the other side. ... In the light of this experience, I am satisfied that if Oram v. Hutt were to come before us today, we should hold that the union had a legitimate interest in the suit and were quite justified in maintaining it: remembering that if the suit had failed, the union would have paid the costs.

In the case of Re Trepca Mines Ltd. ${ }^{10}$ however, Lord Denning indicates the limits to which the courts would go in countenancing such intermeddling in the suits of another:

Maintenance may, I think, nowadays be defined as improperly stirring up litigation and strife by giving aid to one party to bring or defend a claim without 
just cause or excuse. At one time, the limits of 'just cause or excuse' were very narrowly defined. But the law has broadened them very much of late: see Martell v. Consett Iron Co., Ltd. And I hope they will never again be placed in a strait-waistcoat. There is, however, one species of maintenance for which the common law rarely admits of any just cause or excuse, and that is champerty. Champerty is derived from campi partitio (division of the field). It occurs when the person maintaining another stipulates for a share of the proceeds: see the definitions collected by Scrutton, L. J., in Haseldine v. Hosken. The reason why the common law condemns champerty is because of the abuses to which it may give rise. The common law fears that the champertous maintainer might be tempted, for his own personal gain, to inflame the damages, to suppress evidence, or even to suborn witnesses. These fears may be exaggerated; but, be that so or not, the law for centuries has declared champerty to be unlawful, and we cannot do otherwise than enforce the law; and I may observe that it has received statutory support, in the case of solicitors in s. 65(1) (a) and (b) of the Solicitors Act, 1957.

This has been the rationale for the law of maintenance and of champerty as expressed in the courts of the United Kingdom.

\section{THE UNITED STATES}

The contingent fee is the normal and usual method of compensation for the American lawyer representing a plaintiff in a personal injury action as well as numerous other civil causes. ${ }^{11}$

The United States Supreme Court, as early as 1853, in the case of Wylie v. Coxe ${ }^{12}$ decided that claims against the United States could be brought on the basis of the contingent fee.

This acceptance of the contingent fee has been the rule throughout the United States. The only two States that have not adopted the principle are Maine and Massachusetts. ${ }^{13}$ New York in the Field Code of 1848, and the Courts of New Jersey by 1878, had repudiated the English law as it related to champerty. By 1908, the American Bar Association recognized the ethical propriety of contingent fees by its original adoption of Canon 13. In 1933, Canon 13 was amended to read:

A contract for a contingent fee, where sanctioned by law, should be reasonable under all the circumstances of the case, including the risk and uncertainty of the compensation, but should always be subject to the supervision of a court, as to its reasonableness. ${ }^{14}$

Thirty-five of the American States have signified their approval of the A.B.A. Canons, including Canon 13 in its amended form. Twelve other States have adopted their own canons, and have approved of the contingent fee either in those canons or by court decision. In South Carolina, which has not adopted a set of canons, the contingent fee contract has been likewise approved by court decision. The District of Columbia has adopted the A.B.A. Canons and Puerto Rico has adopted its own canons which recognize the propriety of the contingent fee. In most American jurisdictions in practically all personal injury cases the plaintiff's lawyer is engaged under a contingent fee arrangement. It is used to a large extent in will cases, bankruptcy proceedings, workmen's compensation cases, contract actions, stockholder's derivative suits, col-

11 A. D. Youngwood, The Contingent Fee-A Reasonable Alternative (1965), 28 Mod. L. Rev. 330 .

12 Wylie v. Coxe (1853), 15 How. 415; Wright v. Tebbits (1875), 91 U.S. 252; Stanton v. Emrrey (1876), 93 U.S. 548. In all these cases there was no reason given for allowing the contingent fee and It was not until Taylor v. Berniss (1884), 110 U.S. 42 that the United States Supreme Court discussed the question.]

13 In Sullivan v. Goulette (1962), 183 N.E. (2d) 519 (Mass.) the Court sidestepped the issue of contingent fees. $K$. B. Hughes commented on this case in The Contingent Fee Contract in Massachusetts (1963), 43 Bost. L. Rev. 1.

14 Am. Bar Assoc., Canon 13. 
lection suits, tax matters and condemnation proceedings. Contract clauses prohibiting the plaintiff client from settling the action without consent of the attorney are generally enforceable. However, contingency arrangements are discouraged or prohibited in certain types of cases on grounds of public policy. Such cases include prosecution of a criminal case and efforts to secure passage of legislation or the award of a government contract. ${ }^{15}$ Most significant of these categories are matrimonial actions; it is felt that a contingent fee arrangement would encourage the lawyer to consummate the destruction of the family unit rather than seek to conciliate the parties.

There are various and different forms which the contingent fee arrangement may take. The fee may be a flat percentage of any recovery; a series of increasing or decreasing percentages depending on the size of the recovery; a series of increasing percentages depending upon which stage negotiations or litigation has reached when recovery is secured; or perhaps a percentage of the recovery above a stated sum. In most jurisdictions there are no specific maximum percentages which may be charged, although the fee, as with all legal fees, is subject, if challenged, to the ultimate sanction of a review by a court as to its reasonableness. ${ }^{16}$

The first discussion by the United States Supreme Court as to its policy in permitting the use of the contingent fee was in the case of Taylor v. Bemiss ${ }^{17}$ decided in 1884:

And the well known difficulties and delays in obtaining payment of just claims which are not within the ordinary course of procedure of the auditing officers of the government, justifies a liberal compensation in successful cases, where none is to be received in case of failure.

Any other rule would work much hardship in cases of creditors of small means residing far from the seat of government, who can give neither money nor personal attention to securing their rights.

This, however, does not remove the suspicion which naturally attaches to such contracts and where it can be shown that they are obtained from the suitor by any undue influence of the attorney over the client, or by any fraud or imposition, or that the compensation is clearly excessive, so as to amount to extortion, the court will in a proper case protect the party aggrieved.

The Supreme Court of Pennsylvania commented in Williams v. City of Pennsylvania ${ }^{18}$ in 1904 that contingent fees though not illegal in that they enabled some just claims to be recovered which the circumstances of the parties would otherwise defeat, tended to encourage litigation of a speculative and unfounded character which was against the true interest of society.

In Connecticut, the Supreme Court of Errors in Gruskay v. Simenauskas $^{10}$ in 1928 held that a contract for contingency compensation was valid provided the compensation specified was fair and reasonable.

A contract of this character is often the only way by which the poor and helpless can have their rights vindicated and upheld and the injuries they suffered redressed. For the reason that plaintiffs who are poor, or helpless, or in distress of body or mind, may be imposed upon, or yield too easily to unjust professional demands, courts will look closely at a contract for contingency fees, and wherever the compensation exacted is unfair or extortionate it will declare the contract void.

15 In respect to the use of contingent fees in securing a Federal Government contract see (1956), 69 Harv. L. Rev. 1280.

$16 \mathrm{Am}$. Bar Assoc., Canon 13; In Re Estate of Thompson (1967), 232 A. (2d)

625 (Supreme Court of Pennsylvania).

17 (1884), 110 U.S. 42,45 .

18 (1904), $208 \mathrm{~Pa} .282 ; 57$ A. 578.

19 (1928); 140 A. 724, 727; 107 Conn. 380. 
The Supreme Court of New Hampshire dealt exhaustively with the problem of maintenance, champerty and contingency fees in a 1938 decision, Markarian v. Bartis. ${ }^{20}$ It quoted extensively from an early New York case, Thallhimer v. Brinckerhoff ${ }^{21}$ which stated that the English doctrine of maintenance arose from causes peculiar to the state of the society in which it was established, i.e., the power of great men to whom rights of action were transferred in order to obtain support in those actions and that this was considered to endanger justice itself. However, the judgment went on to say at the present time:

'The statutes for the limitation of actions, the statute of frauds, the extension of the action for mischievous prosecutions, and the costs given against unsuccessful parties, have all taken place since the law of maintenance was established; and all these alterations have contributed to prevent or punish groundless and vexatious litigations.' Thallimer v. Brinckerhoff, 3 Cow., N.Y. 623, 644; 15 Am. Dec. 308.

In 1951 the Supreme Court of New Jersey (Appellate Division) followed precedents in Hughes v. Eisner ${ }^{22}$ and stated that, if such agreements could not be enforced, there must be many cases in which the poor would be unable to assert their rights.

The Courts in the United States, nonetheless, have generally imposed on the contingent fee arrangements the necessity of them being "reasonable"23 and not against "public policy."24

The great weight of authority recognizes the validity of contracts for contingency fees provided such contracts are not in contravention of public policy, and it is only when the attorney has taken advantage of the claimant by reason of his poverty, or the surrounding circumstances, to exact an unreasonable and unconscionable proportion of such claim that it is condemned.25

... any fee ... must not be obtained by fraud, mistake or undue influence, and must not be oppressive or extortionate. ${ }^{26}$

From the American case law it is clear that the courts in the United States considered that they were dealing with a different "environment" and that a system of laws could not be transplanted from one society to another without certain alterations. It is equally clear that these courts also did not view "contingency arrangements" with any ethical repugnance.

\section{CANADA}

The contingency fee arrangement is not permitted in Ontario, Nova Scotia, Prince Edward Island and Newfoundland. In New Brunswick the legal profession has until recently been against contingent fees but some doubt has arisen due to a decision rendered in 1962 which held the charging of fees on a contingency basis to be legitimate. In Manitoba, by statute, it has been made legitimate to charge contingent fees. In British Columbia it has in certain cases been accepted by the courts. At the time of writing this article, Quebec, Alberta and Saskatchewan did not allow remuneration to be based on a contingency fee; but these three Provinces are presently contemplating legislation to alter this situation.

20 (1938) 199A. 573, 576. See also: In Re Cohen's Estate (1944), 152 Pac. (2d) 485, 489; Hollister v. Ulvi (1937), 271, N.W. 493, 497, (Supreme Court of Minnesota).

13 Cow. N. 623 ; 15 Am. Dec. 308

22 (1951), 81 A. (2d) $394,397$.

23 In Re Estate of Thompson (1967), 232 A. (2d) 625 (Supreme Court of Pennsylvania) : Holt v. Swenson (1958), 90 N.W.' (2d) 724 (Supreme Court of Minnesota).

24 State ex rel. Nebraska State Bar Association v. Jensen (1962). 105 N.W. (2d) 459

(Neb.); but see Mahoney v. Sharff (1961), 12 Cal. Rptr. 515 (Cal. App. Div.).

25 Hollister v. Ulvi, op. cit. supra, n. 20 at 497.

20 Smith v. Kingsport Press Inc. (1966), 263 F. Supp. 771 (U.S. Dist. Ct.). 


\section{Ontario}

In Ontario, the use of contingent fees is expressly prohibited by the Solicitors Act, R.S.O. 1960, c. 378, s.59 and paragraph 7 of The Canons of Ethics which are Rule 1 of the Professional Conduct Handbook. ${ }^{27}$ The case law in respect to contingent fees is fairly limited and with perhaps three exceptions the cases do not discuss the reasons for the law. ${ }^{28}$

In the early Ontario case of Carr et al v. Tannahill ${ }^{29}$ it is stated that the use of contingency fees would likely lead to perjury and to a perversion of justice and that it would clearly be against public policy. The latter is defined in terms of the factors amounting to maintenance and champerty, and therefore is tautalogical. In a later case of $R e$ Solicitor $^{20}$ more extensive reasons are given by Boyd, C.:

The confidential relation between lawyer and client forbids any bargain being made by which the practitioner shall draw a larger return out of litigation than is sanctioned by the tariff and the practice of the Courts. Especially does the law forbid any agreement for the lawyer to share in the proceeds of a litigated claim as compensation for his services. Such a transaction is in contravention of the statute relating to champerty, and it is also a violation of the solemn engagement entered into by the barrister upon his call to the Bar.

The effect of the agreement first made is that the solicitor and client embark in a joint speculation to be prosecuted in the Court for their joint advantagethe client bringing in his claim for injuries and the lawyer contributing his skill and service. When the professional man becomes a covert co-litigant instead of an independent advisor, many are the temptations to secure success by unworthy means. But I need not dwell on the ethical aspects; enough that the solicitor's action is contrary to law and in violation of his oath of office.

There may be some laxity of opinion and perhaps of practice in the careful observance of a high standard of honour in the stress and struggle of modern life; but while the profession is constituted as it is practitioners must not be allowed to violate with impunity the safeguards which exist for the well-being of society. True it is that in some or perhaps many of the neighbouring States it is permissible to drive such bargains and to conduct cases on the footing of contingent fees, but many eminent lawyers lament the professional degradation which it involves. One who was ambassador to the British Court spoke at a recent bar association of the fatal and pernicious charge made several generations ago by statute by which lawyers and clients are permitted to make any agreement they please as to compensation-'so that contingent fees, contracts for shares and even contracts to pay all the expenses and take half the results are permissible, ... . How,' he says, 'can the Courts put full faith in the sincerity of our labours as aids to them in the administration of justice if they have reason to suspect us of having bargained for a share of a result?' /And at an earlier day the point was more tersely put by David Webster: 'I never engage on contingencies merely, for that would make me a mere party to a law suit.'

Things have gone from bad to worse on this downward grade, for now the 'American Ambulance-Chaser' has become a visible factor in so called professional life. His function is to hustle after injured sufferers, with shameless

27 Solicitors Act, R.S.O. 1960, c. 378, s. 59:

"Nothing in sections 47 and 64 gives validity to a purchase by a solicitor of the interest or any part of the interest of his client in any action or other contentious proceeding to be brought or maintained, or gives validity to an agreement by which a solicitor retained or employed to prosecute an action or proceeding stipulates for a solicitor retained or employed to prosecute an action or proceeding stipulates for to be paid to him is a percentage of the amount or value of the property recovered or preserved or otherwise determinable by such amount or value or dependent upon the result of the action or proceeding."

Paragraph 7 of Canon 3 of the Canons of Ethics which are Ruling 1 of the Professional Conduct Handbook reads in part:

A lawyer "... should not accept as by law expressly sanctioned, acquire by purchase, or otherwise, any interest in the subject matter of the litigation being conducted by him ..."

See also: Champerty Act, R.S.O. 1897, c. 327.

$28 \mathrm{Kerr}$ and Brown v. Brunton (1865), 24 U.C.Q.B. 390 395; Little v. Hawkins (1872), 19 Gr. Ch. 267, 269; Langtry v. Dumoulin (1884-5), 7 O.R. 644, 660; Re Canon, Oates v. Cannon (1887), 13 O.R. 70, 79; Re Solicitor (1903), 2 O.W.R.' 268; Re Dyer \& Town of Brampton (1905), 5 O.W.R. 668; In Re Solicitors, Clark v. Lee (1905) O.L.R. 708; Colville v. Small (1910), 22 O.L.R. 33; Sheppard v. Frind, [1941] S.C.R. 531 (Ont); Biro v. Sheldon (1965), 46 D.L.R. (2d) 610 (Ont.); [In these cases the English law on champerty and maintenance is followed and approved of without a discussion of the reasons for such princlples].

29 discussion of 30 U.C.Q.B. 217.

80 (1907), 14 O.I.R. 464, 465. 
solicitation, to coach witnesses, interview jurymen, compass in any way a favourable verdict and enjoy some generous share of the spoils. Already in more than one State statutes have been passed to put an end, if possible, to such disgraceful practices. It is well, then, in Ontario to repress the beginnings of anything savouring of this kind of illicit procedure.

A somewhat more moderate view is expressed by Meredith, C. J. O., in the case of MacMahon v. Taugher: ${ }^{31}$

I prefer the view expressed by Sir Montague E. Smith in delivering the judgment of the Judicial Committee of the Privy Council in Ram Coomar Coondee v. Chunder Canto Mookerjee (1876), 2 App. Cas. 186. In that case it was decided that the English laws of maintenance and champerty were not of force as specific laws in India, and Sir Montague E. Smith said (p. 209) that, while that was the case, it seemed clear upon the authorities that contracts of that character ought under certain circumstances to be held invalid as being against public policy, and added (p. 211): "Their Lordships think it may properly be inferred from the decisions'- to which he had referred-'that a fair agreement to supply funds to carry on a suit in consideration of having a share of the property, if recovered, ought not to be regarded as being, per se, opposed to public policy. Indeed, cases may be easily supposed in which it would be in furtherance of right and justice, and necessary to resist oppression, that a suitor who had a just title to property, and no means except the property itself, should be assisted in this manner. But agreements of this kind ought to be carefully watched, and when found to be extortionate and unconscionable, so as to be inequitable against the party ... effect ought not to be given to them.'

The trend of modern opinion is . . . in accord with that expressed by Sir Montague E. Smith; and in many of the States of the neighbouring Republic an attorney and his client may lawfully agree that the attorney's compensation for services rendered in recovering property for his client shall be a part of the property or a proportion of its value, and that such an agreement is valid and binding upon the client, subject always to the condition that the compensation is not extortionate and unconscionable so as to be inequitable against the client; and, although such agreements are not valid according to the law of Ontario, there are many who think that no harm would be done if a similar latitude were by legislation allowed to solicitors in this Province.

\section{Quebec}

The basic case as to the law of Quebec on the use of contingent fees is a decision of the Supreme Court of Canada in 1891 delivered in Price v. Mercier ${ }^{32}$ where Taschereau, J., said:

And the sale of litigious rights to advocates or attornies practising before the courts under the jurisdiction of which those rights would fall is expressly prohibited by art. 1485 C. C. ... As well said by the Supreme Court of Louisiana in a recent case under the article of their code corresponding with our article 1485: "The elevated standard which the learned profession must occupy in public esteem makes it the imperative duty of courts to exact a rigid compliance with a rule calculated to enhance the honor and usefulness of the profession'. . . . Then, apart from the consideration that this sale was made to a practising attorney it seems to be unlawful and void as tainted with champerty, an offence punishable under the criminal law of the country.

In a judgment of the Court in 1904, the above decision was followed in Meloche v. Déguire ${ }^{33}$ where Taschereau, C. J., said

There are cases, no doubt, as argued by the respondents, where it has been held that certain special civil and criminal laws of England did not extend to its subsequently acquired possessions. But the reasons upon which these decisions have been given have no more application to the Province of Quebec in relation to the law of champerty than they have to the rest of the Dominion. The offence has always been considered as 'one against public justice, in that it tends to keep alive strife and contention, and the object of the law is to hinder the 'perverting of the remedial process of the law into an engine of oppression.' It is a law of public order, the principles of which and the reasons for which apply as well to Quebec as to England or the other parts of this Dominion. 
In a 1932 decision M. le juge Le Tourneau again held that a contingent fee agreement was unlawful:

Je ne m'attarderai pas à distinguer entre ces prohibitions due pacte de 'quota litis' qui nous sont venues avec l'ancien droit francais, et celles du 'maintence' ou du 'champerty' que nous tenons du 'common law' anglais, puisque le résultat reste le même et que sauf certains cas d'exception pour le 'maintenance', qui ne se recontrent pas ici, la convention est dans chacun du ces cas, tenue est dans chacun des ces cas, tenue pour nulle parce qu'immorale et contraire à l'ordre public. ${ }^{34}$

In 1938 the case of Rex v. Bordoff ${ }^{35}$ followed the English and earlier Quebec authorities:

le 'champerty' et 'maintenance' sont donc reconnus en Angleterre comme offenses d'apres le 'common law'. Notre jurisprudence a également sanctionné ce principe, et est a l'effect que le 'champerty' et 'maintenance' sont des offenses suivant notre droit!

The latest judicial comment for Quebec by way of the Supreme Court of Canada in respect of champerty and contingency fees approved the orthodox English position. In the case of Goodman v. Rex ${ }^{30}$ Kerwin, J., stated:

These references to the speeches in the House of Lords in the Neville case indicate that the views previously expressed by various writers of standing and by a number of very able judges have not been departed from and that there must exist that officious interference, that introduction of parties to enforce rights which others are not disposed to enforce, that stirring up of strife, to constitute the crime of maintenance. In the present case [L.] was disposed to enforce his claim, and in fact had already consulted attorneys before his wife approached the appellant. The appellant did not intervene on his own initiative and took no action that may be in any way described as stirring up strife and litigation.

The Bar of the Province of Quebec has recently adopted by-laws regarding 'extrajudicial fees' which came into force in February, 1968. ${ }^{37}$ By section 87 of Rule 1, the contingent fee is allowed in litigious matters but this "extrajudicial fee," which is in addition to the judicial costs paid by the opposing party and the extrajudicial disbursements, must not exceed $30 \%$ of the amount obtained and collected.

84 Therien v. Beauchamp (1932), 53 Rap. Jud. Off. Que., Banc du Roi, 147.

35 (1938), 76 Que. S.C. 83.

80 [1939]' S.C.R. 446, 453 (Que).

37 Rule 1:

"82. Except in the cases expressly provided for by articles 86 and 87, or in exceptional cases warranted by considerations of a charitable or family nature, an advocate shall not:

(a) agree in advance with a client not to charge him for disbursements or fees,

(b) agree in advance with a client to reduce the fees and disbursements established by the tariffs or the by-laws;

(c) offer any such bargain to a particular client or to the public in general.

"86(1) When an advocate's mandate is solely for the collection of accounts for goods sold, rental due, services rendered or work done, taxes, assessments, dues and fees, amounts due on bills of exchange or acknowledgements of debt, hypothecary obliamounts due on bills of exchange or acknowledgements of debt, hypothecary oblishall be fixed in accordance with the following scale which is obligatory:

(3) In the cases provided for in paragraph 1, an advocate may agree in advance in writing with his client and on the terms defined in such agreement not to charge him any costs, fee or disbursements whatsoever in return for the payment of a percentage of the amount collected on behalf of or by the client, such percentage not to be less than that provided for in paragraph 1 .

" 87 (1) In the cases not covered by article 86 an advocate may agree in writing with his client, to charge him an extrajudiclal fee not exceeding $30 \%$ of the amount obtained and collected form any source whatsoever, whether as a result of a settlement or and collected form any source whatsoever, whether as a result of a settlement or and the extrajudicial disbursements." 
Newfoundland, Prince Edward Island and Nova Scotia

The contingent fee arrangement is not permitted in Newfoundland or in Prince Edward Island. ${ }^{38}$

Nova Scotia, it appears, does not allow the contingent fee to be used but this supposition is based merely on the fact that champertous arrangements are struck down. ${ }^{39}$

\section{New Brunswick}

Although the Barristers' Society of New Brunswick has always been against contingent fees it appears that in the last few years a change is taking place. And this is reflected in the unreported decision of the Supreme Court of New Brunswick, Queen's Bench Division, in the case of Hogan v. Hello, Hivaire, Brideau and Buraghier. The decision was handed down by J. E. Michaud, C.J., on March 14, 1962:

On the evidence I find that there was no vicious or improper intervention in litigation nor anything improper done by the plaintiff, and I find the agreement suggested by the defendants and agreed to by the plaintiff to give the latter's services on a contingent basis is legal and enforceable to the extent of its fair construction and interpretation.

\section{Manitoba}

Since 1890 there has appeared in the Manitoba statutes a section allowing litigation to be conducted on a contingency fee basis. ${ }^{40}$ In the 1956 revision this provision was continued with some changes and the regulation (supervision) of the use of the contingent fee was clearly set forth. ${ }^{41}$ Subsection 4 of Section 48 provides for a declaration by a judge of the Court of Queen's Bench in Chambers whether the contract is fair and reasonable to the client. The attitude of the judiciary in respect to this section is clearly delineated in the case of In Re Law

38 There is no case law or ruling by the respective societies on the question of contingent fees that has been brought to the writer's notice. But the Law Society of Prince Edward Island has stated that contingent fees are not permitted. For the lack of better information it is assumed that Newfoundland follows the English position that such agreements are champertous.

39 Craig v. Thompson (1907), 42 N.S.R. 150; Allan v. McHeffey (1861), 5 N.S.R. 120.

40 S.M. 1890 , c. 2, s. 37 ;

R.S.M. 1891, c. 83, s. 68 ;

R.S.M. 1902, c. 95, s. 65 ;

R.S.M. 1913, c. 111, 8. 73;

S.M. 1932 , c. 22, s. $3(5)$;

R.S.M. 1940, c. 115 , s. 74;

R.S.M. 1954, c. 139, 8. 74;

R.S.M. 1956 , c. 39 , s. 48

11 Law Society Act, R.S.M. 1956, c. 39 :

"48. (1) In this section 'contingency contract' means a contract made by a solfcitor or barrister practising in the province, with a person (herein referred to as the client'), as to the remuneration to be paid to or retained by, the solicitor or barrister for services rendered or to be rendered to the client whereby, for those services, the solicitor or barrister is to receive or retain, in lieu of or in addition to any remuneration that he might otherwise be entitled to,

(a) a portion of the proceeds of the subject matter of the action or proceedings

in which the solicitor or barrister is or is to be employed;

(b) a portion of the money or property in respect of which the solfcitor or barrister is or may be retained or employed, whether or not an action or proceeding therefore has been commenced or is contemplated; or

(c) a commission or a percentage of the amount recovered or defended or of

the value of the property about which any transaction, action, or proceeding, is the value of the property about which any transaction, action, or proceeding. is

(2) At the time of making a contingency contract the solicitor or barrister who is a party thereto shall deliver to, and leave with, the client a copy of the contingency contract with a copy of subsections (4). (5) and (6) attached thereto.

(3) A solicitor or barrister who has not complied with subsection (2) is not entitled to any remuneration exceeding that to which he would have been entitled had no such contingency contract been made.

(4) Where a contingency contract has been entered into, the client may, at any time within three months after payment to, or retention by, the solicitor or barrister 
Society Act, Galbraith v. Murray, Robertson and Thomas. ${ }^{42}$ It was held that this "fairness" related to the means by which the agreement was brought about and "reasonable" to the quantity of remuneration thereby enuring to the solicitor. In respect to the latter, Kilgour, J., stated:

In determining whether the amount is reasonable, the actual work which the solicitor is called upon to do is undoubtedly a factor, though not the sole factor, to be taken into account (see Re Stuart, Ex.p. Cathcart, supra). If it were the only factor, the express legislative sanction given to contracts of this character would be nugatory and meaningless. The Legislature, permitting solicitors to contract for remuneration 'in the way of commission or percentage on the amount recovered' obviously intended that the remuneration should be for the risk taken as well as for the work done. The excess over the sum ordinarily taxable which the solicitor may reasonably (from the client's viewpoint) contract for by way of percentage must depend, one would say, on the reality and extent of the risk he undertakes, and the amount of work expected normally to be done, that is to say, the outlook at the time the solicitor actually assumes his obligation.

The basic case in Manitoba in this area is Thomson v. Wishart ${ }^{43}$ which contains two most important points. The first is that different societies give rise to different laws. Per Perdue, J. A.:

For more than a hundred years after the date of the Company's charter there were no civil or criminal courts in Rupert's Land and no litigation to stir up or maintain. The law of maintenance and champerty could therefore have no application to the territory in the year 1670, and could not be held to have been introduced as a part of the law brought with them by a few English fur traders.

The second aspect is that the Court does not view the contingent fee as being something repugnant or morally reprehensible.

Section 65 of the Law Society Act has been in force for twenty years and has been frequently acted upon. In the main, the results of the provision have been beneficial to suitors who had not the means of embarking in expensive litigation. I confess that I can see nothing morally wrong in such a bargain between solicitor and client.

\section{Saskatchewan}

The Law Society of Saskatchewan does not permit its members to charge on the basis of contingent fees.

In the decision of the Saskatchewan King's Bench in Carlson v. Chambers $^{44}$ the Court examined the law of maintenance and champerty and held that there could be no maintenance unless there was conduct involving officious or improper interference in the case, or an attempt to stir up strife or litigation or something that in a legal sense is immoral or done with an improper motive.

In 1967 there was submitted to the Saskatchewan Legislature an amendment to the Legal Profession Act to authorize the Law Society

of any remuneration provided for in the contingency contract, and whether before or after the payment or retention, apply by way of originating notice to a judge of the Court of Queen's Bench in chambers for a declaration that the contract is not fair and reasonable to the client.

(5) Upon the hearing of the application the judge shall inquire into the facts; and, if it appears to him that the contingency contract is not fair and reasonable to the client, he shall declare it to be void and shall order the costs, fees, charges, and disbursements, of the solicitor or barrister in respect of the business done to be taxed in the same manner as if no contingency contract had been made.

(6) Where the remuneration has been received or retained by the solicitor or barrister and exceeds the amount so taxed, the judge shall order repayment to the client of the excess and may give all directions necessary or proper for the purpose of carrying any such order into effect or otherwise consequential thereon as to the judge seems meet.

(7) For the purposes aforesaid the Judge, may take evidence either by affidavit or viva voce, as to the judge may seem just."

42 [1930] 4 D.L.R. 1004, 1006 (Man. K.B.).

43 (1910), 19 Man. R. 340, 345 \& 349 (Man. C.A.).

4t [1947] 2 D.I.R. 667, 672 . 
to make rules in connection with contingent fees but to date the Legislature has not seen fit to pass this amendment to the Act.

\section{Alberta}

The most recent judicial opinion in Alberta is that contingent fee arrangements are bad.45 The Bar of Alberta is governed by Rule 749 of the Rules of the Supreme Court of Alberta, 1944, which explicitly prohibits the use of the contingent fee. ${ }^{46}$ However, the Statutes of Alberta, 1967, Chapter 42, "An Act to Amend the Judicature Act," provides for a contingency agreement:

38 (a) (i) No agreement between a barrister and solicitor and a client respecting the barrister's and solicitor's fees is invalid or unenforceable solely by reason of the fact that the amount of the fee is contingent or dependent, in whole or in part, upon the successful accomplishment or disposing of the matter to which the fee relates, if the agreement is made in compliance with the rules made under this section.

The draft rules pertaining to contingent fees form part of the revised rules of court which it is hoped will be brought into force early in 1968. The use of the contingent fee will be subject to the supervision of the clerk of the court and on the request of the client may be removed or appealed to a Supreme Court Judge.

\section{British Columbia}

Very early, British Columbia courts decided against allowing contingent fees on the grounds of champerty and maintenance.

In 1901 the then Attorney-General introduced an amendment to the Legal Professions Act, S.B.C. 1901, c. 4, s. 1, which was later amended in R.S.B.C. 1911, c.136, s.97:

Notwithstanding any law or usage to the contrary, any solicitor or barrister in the Province may contract, either under seal or otherwise, with any person as to the remuneration to be paid him for services rendered or to be rendered to such person in lieu of or in addition to the costs which are allowed to said solicitor or barrister, and the contract entered into may provide that such solicitor or barrister is to receive a portion of the proceeds of the subjectmatter of the action or suit in which any solicitor or barrister is to be employed, or a portion of the moneys or property as to which such solicitor or barrister may be retained, whether an action or suit is brought for the same or a defence entered or not, and such remuneration may also be in the way of commission or percentage on the amount recovered or defended against, or on the value of the property about which any action, suit, or transaction is concerned.

45 Morrison v. Mills and Mills (1963), 38 D.L.R. (2d) 489, 491 (Alberta Supreme Court). s6 Rule 749:

"A barrister and solicitor may make an agreement in writing with the client respecting the amount and manner of payment for the whole or any part of any past or future services, fees, charges or disbursements in respect of business done or to be fone by such barrister and solicitor, either by a gross sum or by commission or percentage or by salary or otherwise, and either at the same or at a greater or a less rate as or than the rate at which he would othrewise be entitled to be remunerated. "Provided always, that when any such agreement shall be made in respect of business done or to be done in any action the amount payable under the agreement shall not be receivable by the barrister or solicitor until the agreement has been examined and allowed by the taxing officer of the court having power to enforce the asreement in the judicial district in which the solicitor resides, and either party may require the taxing officer to take the opinion of a judge thereon; and such judge shall have power elther to reduce the amount payable under the agreement or order the agreement to be cancelled and the costs, fees, charges and disbursements in respect of the business done to be taxed in the same manner as if no such agreement had been made;

"And provided further, that nothing herein contained shall be construed to give validity to any purchase by a barrister and solicitor of the interest or any part of the interest of his client in any suit. action or other contentious proceeding to be brought or maintained, or to give validity to any agreement by which a barrister or solleclior retained or employed to prosecute any suit, action or other contentious proceeding
stipulates for payment only in the event of success in such suit, action or proceeding." 
However, the courts in British Columbia held that such legislation was ultra vires the Province. Per Morrison, J., in Taylor v. Mackintosh (1924): ${ }^{47}$

That piece of legislation, which is unambiguous, bold phraseology, to my mind, clearly attempts to delete the law as to champerty as it stood in British Columbia and was, therefore, an open invasion by the Provincial Legislature of the field of criminal law occupied exclusively by the Federal Parliament. Enterprising excursions of that sort, be they never so alluring, are rendered futile because they are, in plain English, beyond the strength of the assailants or in the classical language of the lawyer ultra vires of the Legislature.

On appeal, the Court was composed of three members. ${ }^{48}$ MacDonald, C. J. A., was of the opinion that that part of the section authorizing a solicitor to bargain for a share in the proceeds of the litigation was ultra vires, McPhillips, J. A., was of the opinion that the section was intra vires, and Martin, J. A., decided the case on another ground.

In 1927, in the case of Re Legal Professions Act ${ }^{40}$ three of five Judges of the Court of Appeal decided that champerty was part of the criminal law of England introduced into British Columbia and that the Provincial Legislature could not legalize champertous agreements.

It is to be noted that in Manitoba, Perdue, J. A., in the case of Thomson v. Wishart ${ }^{50}$ resolved the question of whether Provincial legislation permitting contingent fees was ultra vires by holding:

By section 12 of the Criminal Code, R.S.C. 1906, c. 146, it is declared that: "The criminal law of England as it existed on the fifteenth day of July, one thousand eight hundred and seventy, in so far as it is applicable to the Province of Manitoba, and in so far as it has not been repealed, as to the Province, by any Act of the Parliament of the United Kingdom, or by this Act, or any other Act modified or affected, as to the Province, by any such Act, shall be the criminal law of Manitoba.'

It is to be observed that section 12 of the Code contains the qualification 'in so far as it (the original law) is applicable to the Province of Manitoba.' The meaning, therefore, is that not all the criminal laws of England were introduced, but only those that were applicable to the Province, that is, to the conditions of life then existing in the Province. In the sections of the Code (10 \& 11) which deal with the introduction of the criminal law into Ontario and British Columbia, no such qualification as the above is found. It is, therefore, to be assumed that Parliament did not intend to introduce into the Province of Manitoba obsolete criminal laws, or any law applicable to the then existing conditions of society in that Province.

By Section 8 of The Criminal Code, 1953-54, c. 51, the common law offences of champerty and maintenance were abolished. In 1963, Lord, J., in the case of Amacher v. Erickson ${ }^{51}$ held that an agreement between the plaintiff, an accountant, and the defendant for the payment to the plaintiff of a percentage of the amount recovered on an income tax appeal was neither maintenance nor champertous. He based his decision on the proposition that there could be no champerty without maintenance, that there must be present in champerty as in maintenance an officious intermeddling, a stirring up of strife or other improper motive. He then went on to say:

In this case there is no stirring up of strife or litigation; the proceedings had already been commenced with the full intention of going as far in litigation as possible to obtain the refund. There was no officious interference or intermeddling. Amacher came into the picture by a chance meeting in the bank with Erickson. The initiative seems to have come from the latter to employ

47 [1924] 1 D.L.R. 877, 880

48 1924] 3 D.L.R. 926 .

40 [1927] 4 D.L.R. 195.

50 Op. cit. supra n. 43 at 344352

B1 (1963), 42 W.W.R. 348, $350 \& 352$. 
Amacher. There is no indication in the evidence that Amacher in any way tried to force his employment upon Erickson. . . .

But the reason for so declaring it has now disappeared by reason of sec. 8 of the new Criminal Code, 1953-54, ch. 51, which provides that no person shall be convicted of an offence at common law.

The offences may not have been abolished, but parliament has seen fit to make them ineffective and, in the result, common-law offences should not now be regarded as a crime under the criminal law of Canada. In any event one inescapable conclusion which may be drawn from sec. 8 of the Code is that parliament does not consider maintenance and champerty to be against public policy or the public interest. In fact, the royal commission report for the drafting of a new Code refers to these common-law offences as 'obsolete and archaic' and did not include them in their codification of the criminal law.

The judgment of Ford, J., in Amacher v. Erickson was expressly affirmed by the decision of Whittaker, J. A., in the case of Monteith v. Calladine $e^{52}$ who said:

It would appear, therefore, that champerty is maintenance plus an agreement to share in the proceeds, and that while there can be maintenance without champerty, there can be no champerty without maintenance. There must be present in champerty as in maintenance an officious intermeddling, a stirring up of strife, or other improper motive.

The matter of contingent fees was considered by the Benchers of the Law Society of British Columbia at their meeting on November 24, 1967. At that time, the Benchers appeared to accept the proposition that the fact that an agreed fee was the percentage of the amount to be recovered did not, per se, make the contract champertous.

It is with great respect difficult for the writer to accept this line of reasoning. Maintenance is a tort as well as a crime. It was also an equitable defence to an action on the agreement. The fact that the Criminal Code was amended should make little difference to the rights of litigants in a civil proceeding. The only real effect is that it will obviate the argument that it is ultra vires Provincial Legislatures to pass laws relating to contingent fees. Nor is it appealing to say that an agreement to pay a contingent fee may not be maintenance if there is no stirring up of strife. This conclusion appears to be directly contrary to the decision of the Court of Appeal in Re Trepca Mines Ltd.ss

\section{DISCUSSION OF THE PROBLEM}

The argument which is commonly made is that all compensation in this area is contingent upon results. But this is an exercise in semantics. A fee which is based on contingency is quite distinct from a fee measured by results. Compensation based upon the value of services rendered is obviously affected in size and amount by the benefit to the client, but this compensation is measured after the service is performed and is determined by the actual facts in retrospect with full disclosure of the facts to the client. The fundamental aspect of the contingency fee agreement is that it is usually made before the action is commenced.

It is clear that there is nothing wrong in a proper case with a solicitor undertaking litigation when he knows that he will not get paid unless the action is successful. Lord Russell of Killowen in a charge to the jury in Ladd v. London Railway ${ }^{54}$ said this:

52 (1964), 49 W.W.R. 641, 652

53 Loc. cit. supra, n. 10.

54110 L.T. Jour. 80. See also: Rich v. Cook (1910), 110 L.T. Jour. 94; Re Solicitor loc. cit. supra n. 30; Wiggins v. Lavy (1928), 44 L.T.R. T21. 
In reference to the subject of speculative actions generally, I think it right to say on the part of the profession and the class of persons who were litigants in such cases, that it is perfectly consistent with the highest honour to take up a speculative action in this sense, viz., that if a solicitor heard of an injury to a client and honestly took pains to inform himself whether there was a bona fide cause of action, it was consistent with the honour of the profession that the solicitor should take up the action. It would be an evil thing if there were no solicitors to take up such cases, because there was in this country no machinery by which the wrongs of the humbler classes could be vindicated. Law was an expensive luxury, and justice would very often not be done if there were no professional men to take up their cases and take the chances of ultimate payment; but this was on the supposition that the solicitor had honestly satisfied himself by careful inquiry that an honest case existed.

Similarly it is not improper for a solicitor, or any other person, to supply funds to enable a litigant to defray the costs of bringing on the action provided there be no malice, officious inter-meddling or desire to stir up strife in so doing. This proposition is demonstrated by the words of Davies, J., in Newswander v. Giegerich. ${ }^{\mathrm{s5}}$

It would indeed at the present day be a startling proposition to put forward that every one was guilty of the crime of maintenance who assisted another in bringing or maintaining an action, irrespective of the results or merits of such action and whether the courts sustained it or not. Many grasping, rich men and soulless corporations would greedily welcome such a determination of the law, because it would enable them successfully to ignore and refuse the claims of every poor man who had not sufficient means himself to prosecute his case in the courts, conscious that if any third person except from charity gave the necessary financial assistance to have justice enforced, as soon as it was enforced the denier of justice could turn round and compel the good Samaritan to pay him all the costs he had incurred in attempting to defeat justice.

Such a condition of things is repugnant to our common sense and the courts have from time to time found it necessary to engraft exceptions upon the law of maintenance making such things and relations as kindred affection or charity, with or without reasonable ground, a lawful excuse for maintaining an action and confining the law to cases where a man improperly and for the purpose of stirring up litigation and strife encourages others to bring actions or to make defences which they had no right to bring or make.

The real difficulty arises in those cases where the solicitor stipulates that his remuneration will be a share of the award. It is a contingent fee of this type that has given rise to considerable criticism, the main points being that:-

1. It is apt to encourage persons to commence or persist in suits which they might not otherwise maintain. It tends to promote vexatious litigation.

2. It is against public policy that litigation should be promoted and supported by those who have no concern in it.

3. Its adoption will lead to a deterioration in the ethical standards of the legal profession. The practitioner might succumb, for reasons of personal gain, to the temptation of securing success by dubious methods, e.g. to inflate the damages, suppress evidence or suborn witnesses.

4. It has a tendency to promote "ambulance chasing." It is impossible to make any sort of reliable statistical study in this area and therefore discussion must be based mainly on one's own personal experience as well as the observations of others. Certainly the spectre of the "ambulance-chaser" has figured prominently in the experience of earlier observers.

In 1914 the Ethics Committee of the State Bar Association of Minnesota reported that one of the firms making a specialty of this class of cases had branch offices 
in 32 cities, with solicitors covering such places as Winnipeg, Houston, New York, Los Angeles and Jacksonville. Another firm employed 45 salaried railroad employees as solicitors, maintained a hospital and medical staff for the purpose of providing medical treatment for non-resident injured persons who were awaiting trial, employed lecturers, and sent out literature to railroad employees, reminding them generally that the courts of Minnesota are the most desirable forum in which to try personal injury cases; that juries in Minnesota are more liberal than in other states; that five-sixths of a jury may find a verdict, and that results can be reached in their courts much more quickly than in the courts of other states. The practices of a group of lawyers of this sort put such a strain upon the courts in various counties of the state and increased the taxes for the maintenance of judicial proceedings to such an extent that the taxpayers were aroused. ${ }^{\mathrm{s}}$

5. It leads to an over-reaching in the obtaining of compensation by sanctioning the making of a bargain whereby the practitioner can obtain a larger return out of the litigation than is warranted.

6. It is often difficult for a defendant to settle at an early stage, where the percentage of the fee is based on a series of increasing percentages depending upon the stage the proceedings have reached when recovery is made.

7. The setting of a percentage of the award makes it appear to the client that there is no relation between the fees charged and the services rendered.

8. While the solicitor and client embark on a joint speculation whereby the solicitor is entitled to share in the profits if successful, he never assumes any responsibility for the costs if unsuccessful.

9. The use of the contingent fee is not in character with the high ethics of the legal profession. The professional man, who ought to observe a high standard of honour, becomes a co-litigant instead of an independent legal advisor. This point was forcefully made by a former President of the New York Bar Association:

The chief cause of detraction from our absolute independence and disinterestedness as advocates is that fatal and pernicious change made several generations ago by statute by which lawyers and clients are permitted to make any agreements they please as to compensation-so that contingent fees, contracts for shares, even contracts for one-half the result of a litigation are permissible and I fear not unknown. ${ }^{67}$

10. It equates the successful outcome of litigation with the successful practice of law.

The advocates of contingent fees on the other hand argue that such a practice:

1. Allows all people with a meritorious claim to pursue their claims with competent legal assistance. This argument is well put by Whittaker, J. A., in Montieth v. Calladine. ${ }^{58}$

Such agreements would not be necessary were all clients wealthy; but unfortunately there are many poor people whose claims would never be tested in court unless solicitors are prepared to do battle on their behalf, running the risk of receiving an inadequate fee if unsuccessful, and being compensated by receipt of more than the usual charges should success attend their efforts.

2. It encourages accident victims to seek legal advice early and be made fully aware of their rights. Furthermore, early retention of a lawyer will increase the Plaintiff's chances of a just settlement for the attorney immediately begins to gather facts about the controversy-a task which

56 Julius Henry Cohen, The Contingent Fee, "The Evening World" (N.Y.C.) March $12,1928$. 57 President Choate, 1907 Presidential Address, New York State Bar Association.

68 Op. cit. supra, $n$. 52 at 652 . 
becomes more difficult as the interval between the occurrence and the investigation lengthens.

3. The lawyer is apt to be more diligent and better results can be thus obtained for a client. Individuals could not afford to pay for the extensive investigations undertaken by lawyers, who would not otherwise be willing to incur the expenses if they were not personally involved in the result.

4. The notion that lawyers are not in some respects businessmen is nonsense. Payment by commission is legitimate. This proposition is convincingly put by a learned American writer: ${ }^{59}$

Is there anything essentially immoral or unethical in engaging a lawyer who shares his client's conviction that the claim is well founded, and who will asssume the risk of prosecuting it for a chance of a fee? It is unethical if speculation as such is unethical. Speculation is a crime, we are told, in Soviet Russia. And it is unethical, if lawyers must sedulously avoid any comparison with businessmen.

5. Much of the criticism levelled at the contingent fee is not of things inherent in the system.

6. A review of the contingent fee arrangement by a judicial officer would give the client sufficient protection.

7. Clients usually prefer a case to be taken on a contingency basis. This tends to minimize the very heavy expenses they may incur in the event of their action being unsuccessful.

Some of the arguments for and against the use of the contingent fee can be disposed of readily. It is far more important that indigent persons be able to have their cases brought to Court by competent counsel, who will be properly compensated, than it is to indulge the fastidious consciences of those who oppose the contingent fee on the ground that this might promote strife and the vexatious use of the judicial system. In a socially conscious society lawyers must see to it that the courts are made available to the rich and poor alike.

Nor can it be convincingly said that there is, per se, anything immoral or unethical about accepting a case on a contingency basis. Jurists of the highest authority have supported it. Lawyers, whose integrity no one could doubt, charge on a contingency fee basis when permitted by law. Ethics cannot be imposed successfully when the vast majority of a group no longer believe them to be the standards by which to govern conduct, far less so when the social conditions which gave birth to those ethical standards have changed to the extent that they have become outmoded.

However, it must be recognized that a system which allows fees to be charged on a contingency basis is fraught with danger and if uncontrolled, will lead to an empirical deterioration in the standards of conduct of the members of the profession.

The answer may perhaps be found in adopting a system of legal aid. Sophisticated legal aid systems are being introduced which make it possible for the courts to be available to a wide range of civil actions brought by persons who could not previously have done so, but yet have rights to be enforced. Where such systems have been adopted the picture is no longer that of the rich and the strong against the poor and the ill-advised. Such systems, however, are expensive and can

59 Radin, Contingent Fees in California (1940), 28 Calif. L. Rev. 587, 590. 
themselves lead to abuses. There is as yet not sufficient experience to pass judgment on the efficacy of such systems in Canada. Even where there is a system of legal aid, much of the expense could be saved in cases where the client and lawyer prefer to proceed on a speculative basis. In any event, unless all provinces in Canada adopt systems for legal aid, the problem will remain unresolved. The mobility of the population and the extension of commercial life today give rise to litigation in a given jurisdiction almost as a matter of chance. It would be most unfortunate if what is regarded as a normal and usual practice in one province is looked down upon in another as being immoral and unethical. Some day, perhaps, the Canadian Bar Association will deal with this disturbing problem.

I have always thought that in the end it is important for an author to be brave enough to give his own opinion on the subject he is discussing. The contingent fee is much akin to sex. At an early age one is taught to abhor it. The first direct encounter with it may come somewhat as a shock. Maturity and experience develop a keen appreciation for its merits. If the contingent fee were approved by the Canadian jurisdictions in carefully controlled circumstances, the practice could enjoy a favourable evolution. 